慶應義塾大学学術情報リポジトリ

Keio Associated Repository of Academic resouces

\begin{tabular}{|c|l|}
\hline Title & $\begin{array}{l}\text { Intermediate species absorbing in the 500-nm region in metal ion mediated nonenzymatic } \\
\text { transamination }\end{array}$ \\
\hline Sub Title & \\
\hline Author & $\begin{array}{l}\text { 松島, 美一(Matsushima, Yoshikazu) } \\
\text { 小島, 美佐(Kojima, Misa) } \\
\text { 永田, 佳子(Nagata, Yoshiko) }\end{array}$ \\
\hline Publisher & 共立薬科大学 \\
\hline Publication year & 1992 \\
\hline Jtitle & $\begin{array}{l}\text { 共立薬科大学研究年報 (The annual report of the Kyoritsu College of } \\
\text { Pharmacy). No.37 (1992.),p.90-90 }\end{array}$ \\
\hline JaLC DOI & \\
\hline Abstract & \\
\hline Notes & 抄録 \\
\hline Genre & Technical Report \\
\hline URL & https://koara.lib.keio.ac.jp/xoonips/modules/xoonips/detail.php?koara_id=AN00062898-0000003 \\
7-0090
\end{tabular}

慶應義塾大学学術情報リポジトリ(KOARA)に掲載されているコンテンツの著作権は、それぞれの著作者、学会または出版社/発行者に帰属し、その権利は著作権法によって 保護されています。引用にあたっては、著作権法を遵守してご利用ください。

The copyrights of content available on the KeiO Associated Repository of Academic resources (KOARA) belong to the respective authors, academic societies, or publishers/issuers, and these rights are protected by the Japanese Copyright Act. When quoting the content, please follow the Japanese copyright act. 
No. 37 (1992)

\title{
INTERMEDIATE SPECIES ABSORBING IN THE 500-nm REGION IN METAL ION MEDIATED NONENZYMATIC TRANSAMINATION*
}

\author{
Yoshikazu Matsushima, Misa KoJima and Yoshiko Nagata \\ 松島美一，小島美佐，永田佳子
}

\begin{abstract}
A key step in the action of almost all pyridoxal enzymes is the formation of a quinonoid species, in which the $\alpha$-carbon in a Schiff base (aldimine) is deprotonated. Several enzymes have been reported to exhibit an intense absorption band in the $500-\mathrm{nm}$ region of the spectrum, which has been ascribed to the species. We reported previously that in methanolic solutions pyridoxal (PL) and ethyl alaninate with $\mathrm{Al}$ (III) gave an intense absorption band at the 500-nm region and the species should serve as a model of the enzymatic intermediate.

We now report that the $500-\mathrm{nm}$ species were observable with divalent transition ions. The species was formed in the isomerization between the ketimine from ethyl pyruvate and pyridoxamine (PM) and the aldimine from ethyl alaninate and PL catalyzed by the 1:1 $\mathrm{Cu}$ (II) chelates of ethylenediamine (en), dipyridyl (dipy) and tripyridyl (tripy). The species was hardly observable without the di- or tridentate ligands such as en. The quinonoid species were stabilized in the ternary complexes such as $\mathrm{Cu}$ (II)-quinonoid-en. The ternary complex was formed with a planar tridentate ligand, tripy, but a similar ternary complex was hardly formed with diethylenetriamine (dien). The fact should indicate the coplanarity of the quinonoid species. Tripy is a tridentate planar ligand, while dien is tridentate and coordinates with $\mathrm{Cu}$ (II) mostly in a nonplanar form.
\end{abstract}

* 本報告はJ. Inorg. Biochem., 43, 231 （1991）に発表. 